\title{
Sertifikasi Tenaga Kerja Konstruksi: Mengikuti Regulasi Pemerintah Ataukah Meningkatkan Kompetensi Bisnis
}

\author{
Kadek Nita Puri Rahayu \\ Bapenda Pasedahan Agung Kabupaten Badung \\ nitharahayu28@gmail.com
}

\begin{abstract}
This study aims to determine whether certification can build business competency or just a mere formality / tick the box. The sampling technique that is done is by conducting interviews with informants and documentation. The informants in the study were determined by purposive sampling method. The informant referred to by the researcher is the first informant or the most suitable key informant is the Project Management Expert who has followed the certification of expertise then the Project Management Expert directs the next informant to the K3 Construction Expert, the K3 Expert Construction then directs the next informant who oversees the course of the project and the Overseer direct the next informant is the Builder who is considered capable of providing information in this study. The results of the study indicate that certification is not a check box / limited to mere formality, but is able to improve the business competencies of the workforce. This can be said by the author because certification is a very important factor to improve the competence and quality of their work, because the skills knowledge gained in the certification program can be applied directly in the field to the maximum, so that the completion of the project is completed on time. The results of the study indicate that certification is not a check box / limited to mere formality, but is able to improve the business competencies of the workforce. This can be said by the author because certification is a very important factor to improve the competence and quality of their work. From the results of interviews conducted by the authors that the implementation of certification has been effective but around 50\% of the workforce has not yet received certification. Therefore, the next researcher is expected to be able to explore more specific information about what factors have caused the workforce to not have been certified.
\end{abstract}

Keywords: Constructional Labor Certification; Business Competency 


\begin{abstract}
Penelitian ini bertujuan untuk mengetahui apakah sertifikasi dapat membangun kompetensi bisnis atau hanya mengikuti regulasi. Teknik pengambilan sampel yang dilakukan yaitu dengan melakukan wawancara terhadap informan dan dokumentasi. Informan dalam penelitian ini, ditentukan dengan metode purposive sampling. Informan yang dimaksud oleh peneliti yaitu informan pertama atau informan kunci yang paling sesuai adalah Tenaga Ahli Manajemen Proyek yang telah mengikuti sertifikasi keahlian kemudian Tenaga Ahli Manajemen Proyek mengarahkan informan berikutnya adalah Tenaga Ahli K3 Konstruksi, Tenaga Ahli K3. Hasil penelitian menunjukkan bahwa sertifikasi bukan hanya sekedar mengikuti regulasi dari Pemerintah tetapi mampu meningkatkan kompetensi bisnis dari para tenaga kerja. Hal tersebut dapat dikatakan oleh penulis karena sertifikasi merupakan faktor yang sangat penting untuk meningkatkan kompetensi dan kualitas kerja mereka. Dari hasil wawancara yang telah dilakukan oleh penulis bahwa penyelenggaraan sertifikasi sudah berjalan efektif namun sekitar $50 \%$ tenaga kerja belum mengikuti sertifikasi.
\end{abstract}

ABSTRAK

\title{
Kata Kunci : Sertifikasi Tenaga Kerja Konstruksi; Kompetensi Bisnis
}




\section{PENDAHULUAN}

Peningkatan persyaratan peraturan untuk sertifikasi keterampilan, keahlian, dan keselamatan selama dua dekade terakhir mendorong pendekatan pemenuhan kewajiban peraturan untuk pelatihan dan organisasi hanya melakukan persyaratan minimum untuk mempertahankan kepatuhan. Tetapi pengurangan yang direncanakan dalam birokrasi keselamatan dan keselamatan dikombinasikan dengan meningkatnya permintaan industri akan keterampilan yang telah terbukti dari kontraktor dan pemasok, serta lintas keterampilan yang telah menjadi sangat penting selama krisis ekonomi yang sedang berlangsung (Darma, 2019).

Namun, ini tidak mengurangi kebutuhan untuk pelatihan, organisasi masih diharuskan untuk memastikan karyawan dilatih dengan benar dan memiliki pengetahuan yang tepat untuk melakukan pekerjaan secara efektif dan aman. Faktanya, sementara pemerintah mundur dari pendekatan preskriptifnya, industri kini melangkah maju dengan organisasi yang menuntut langsung dan karyawan tidak langsung disertifikasi untuk melakukan peran spesifik sebagai prasyarat untuk pekerjaan atau kontrak baru (Dewi dan Darma, 2017).

Memang, sikap ini jauh melampui persyaratan pelatihan yang ditentukan untuk pengembangan karyawan. Dibangun diatas lintas keahlian yang telah memastikan kelangsungan hidup banyak bisnis selama beberapa tahun terakhir, semakin banyak perusahaan sekarang mengakui nilai standar yang diakui secara nasional dan internasional seperti Institute of Leadership and Management (ILM) untuk pengembangan karyawan dan diferensiasi kompetitif.

Keterampilan seseorang didukung dengan adanya sertifikasi karena mereka mendapatkan pengakuan atas kemampuan dan keahlian dari Lembaga yang menangani sertifikasi tersebut dan untuk memenuhi persyaratan perundang-undangan (Nursyirman \& Moedjiman, 2007; Wiandari dan Darma, 2017). Hal tersebut juga telah dituangkan di dalam UU No. 2 Tahun 2017 tentang Jasa Kontruksi, bahwa tenaga kerja konstruksi harus mengikuti sertifikasi keterampilan kerja atau sertifikasi keahlian kerja yang dilakukan oleh Lembaga Pengembangan Jasa Konstruksi (LPJK).

Fenomena yang terjadi di PT. Megatama Karya yaitu sekitar 50\% tenaga kerja belum mengikuti sertifikasi. Oleh karena itu, pihak perusahaan bertindak tegas kepada karyawan yang bersangkutan untuk mengikuti pendidikan, pelatihan, pembinaan, dan pengawasan di lembaga sertifikasi tenaga ahli. ATAKI merupakan lembaga sertifikasi yang bekerjasama dengan PT. Megatama Karya. Lembaga ini yang nantinya akan mengeluarkan SKT (Surat Keterangan Terampil) dan SKA (Surat Keterangan Ahli) kepada kandidat yang telah lulus mengikuti 
pelatihan. Kandidat yang telah lulus mengikuti pelatihan, diharapkan mampu bersaing dengan tenaga kerja dari luar yang berkompeten.

\section{Standar Keterampilan Kerja Konstruksi}

Ketersediaan tenaga kerja konstruksi yang kompeten sangat dibutuhkan. Tidak saja untuk memenuhi kebutuhan pasar kerja domestik, tetapi juga mancanegara, khususnya di tingkat regional Asia Tenggara. Untuk mewujudkannya dibutuhkan pendidikan, pelatihan, Standar Kompetensi, dan tentunya pengakuan akan kompetensi itu sendiri atau sertifikat. Kebutuhan untuk sertifikasi tenaga terampil sangat mendesak. Lembaga Pengembangan Jasa Konstruksi (LPJK) bekerjasama dengan Pusat Pelatihan Jasa Konstruksi (Puslatjakons) sedang mengembangkan bakuan kompetensi untuk 25 jenis keterampilan. Bakuan kompetensi serta cara pengukurannya (uji kompetensi) merupakan tolok ukur penilaian terhadap kemampuan tenaga kerja konstruksi. Bakuan kompetensi ini disebut dengan Standar Kompetensi Kerja Nasional Indonesia (SKKNI). SKKNI sangat diperlukan dalam upaya untuk menghasilkan pembangunan infrastruktur yang bermutu dan tentunya bermanfaat. Untuk mempercepat penyusunan SKKNI tersebut dapat dilakukan adaptasi Standar Kompetensi dari luar negeri.

\section{Sertifikasi Tenaga Kerja Konstruksi}

Sertifikasi adalah proses penilaian untuk mendapatkan pengakuan atas komepetensi dan kemampuan dari seseorang, untuk memenuhi persyaratan perundang-undangan melalui uji kompetensi (Nursyirwan \& Moedjiman, 2007). Sertifikasi merupakan suatu proses penilaian dimana kompetensi dan kemampuan profesi keahlian dan keterampilan di bidang jasa konstruksi seperti disiplin keilmuan dan atau keterampilan tertentu dan atau kefungsian dan/atau keahlian tertentu. Kompetensi merupakan salah satu akar permasalahan yang ada dalam penyelenggaraan jasa konstruksi. Kompetensi sumber daya manusia yaitu tenaga ahli dan terampil tentunya memerlukan persyaratan-persyaratan baku. Tujuan sertifikasi adalah untuk memberikan jaminan terhadap keterampilan, kualitas dan kemampuan kerja dari tenaga kerja konstruksi, sehingga mampu menghasilkan produk konstruksi yang memenuhi standar kualitas yang telah ditetapkan.

\section{Indikator Sertifikasi Tenaga Kerja Konstruksi}

Indikator sertifikasi merupakan dimensi yang dijadikan ukuran sertifikasi. Indikator tersebut sebagai berikut :

a. Keterampilan 
Keterampilan adalah keahlian atau kemampuan yang dimiliki seseorang dalam melaksanakan suatu pekerjaan atau tugas tertentu dengan baik secara fisik maupun mental. Misalnya seseorang yang mendapat tugas sebagai mandor harus memiliki kemampuan dalam mengawasi proyek yang sedang berjalan di lapangan sehingga proyek dapat selesai tepat waktu.

b. Keahlian

Pengalaman adalah suatu kemampuan yang melakukan sesuatu terhadap sebuah peran. Hal itu merupakan kemampuan yang bisa dipindahkan dari satu orang ke orang yang lainnya. Misalnya bagi seorang ahli manajemen proyek harus mampu mengawasi, mengontrol, dan mengecek proyek yang sedang berjalan di lapangan agar tidak terjadi kesalahan fatal yang kemungkinan akan terjadi.

\section{Kompetensi}

Menurut Sutrisno (2009) mengemukakan kompetensi merupakan suatu karakteristik dasar dari seseorang yang dimana yang memungkinkannya untuk memberikan kinerja unggul dalam pekerjaan, peran, atau situasi tertentu. Keterampilan adalah hal-hal yang orang bisa lakukan dengan baik. Pengetahuan adalah apa yang diketahui seseorang tentang suatu topik. (didukung penelitian dari Widiari dan Darma, 2017).

Menurut Wibowo (2012), pengertian Kompetensi merupakan kemampuan untuk melaksanakan pekerjaan atau tugas yang didasari keterampilan maupun pengetahuan dan didukung oleh sikap kerja yang ditetapkan oleh pekerjaan. Kompetensi jugs menunjukkan pengetahuan, keterampilan dan sikap tertentu dari suatu profesi dalam ciri keahlian tertentu, yang menjadi ciri dari seorang professional (didukung penelitian dari Purnantara dan Darma, 2015).

Sedarmayanti (2011) mengemukakan bahwa kompetensi merupakan suatu karakteristik mendasar yang dimiliki seseorang atau manusia yang sangat berpengaruh langsung terhadap kinerja, atau dapat memprediksi kinerja yang sangat baik. Dengan kata lain bahwa kompetensi meupakan apa yang outstanding performers lakukan lebih sering pada lebih banyak situasi, dengan hasil yang lebih baik, daripada apa yang dilakukan dalam penilai kebijakan. 


\section{Indikator Kompetensi}

Indikator kompetensi merupakan pengukur dari faktor yang mempengaruhi kompetensi atau sebagai penjelasan dari faktor kompetensi. Indikator tersebut sebagai berikut :

a. Karakteristik

Karakteristik adalah watak atau karakter yang membuat seseorang untuk berperilaku atau bagaimana seseorang merespon sesuatu dengan cara tertentu. Misalnya percaya diri, kontrol diri, stress atau ketabahan.

b. Keterampilan

Keterampilan adalah keahlian atau kemampuan yang dimiliki seseorang dalam melaksanakan suatu pekerjaan atau tugas tertentu dengan baik secara fisik maupun mental. Misalnya seseorang yang mendapat tugas di bidang accounting harus memiliki kemampuan dalam menyusun laporan keuangan dan pembukuan.

c. Keahlian

Pengalaman adalah suatu kemampuan yang melakukan sesuatu terhadap sebuah peran. Hal itu merupakan kemampuan yang bisa dipindahkan dari satu orang ke orang yang lainnya. Misalnya bagi seorang akuntan, aritmatika merupakan sebuah keahlian. Sedangkan bagi seorang pilot, mekanika gerakan miring, memutar, dan juga menukik merupakan keahlian.

\section{Kerangka Konseptual}

Penelitian ini nantinya hanya meneliti tentang penerapan dan pemahaman kompetensi tenaga kerja konstruksi dalam meningkatkan kinerja perusahaan pada lokasi penelitian. Kompetensi merupakan keahlian atau kemampuan seseorang dalam melaksanakan tugas atau pekerjaan. Tenaga kerja yang tidak berkompeten akan berdampak terhadap penurunan kinerja perusahaan. Maka dari itu pimpinan perlu menerapkan dan memahami kompetensi tenaga kerja konstruksi yakni dengan sertifikasi keahlian dan keterampilan tenaga kerja agar kinerja perusahaan meningkat.

Hal tersebut dapat digambarkan seperti kerangka konseptual di bawah ini : 


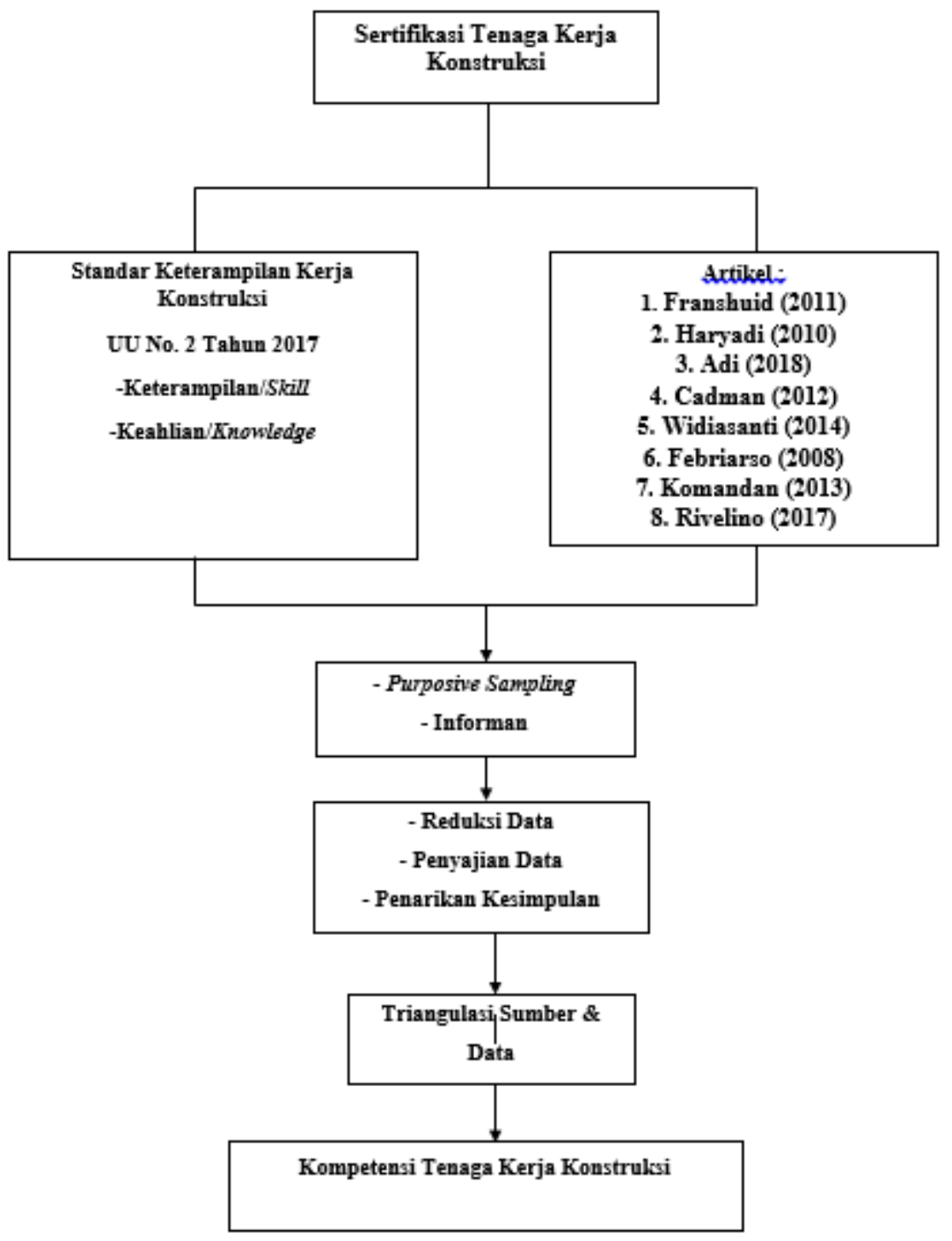

\section{METODE PENELITIAN}

Desain penelitian pada penelitian ini menggunakan pendekatan kualitatif dengan metode analisis deskriptif. Pendekatan kualitatif diyakini mampu mengarahkan pencarian-pencarian konsep baru melalui intepretasi proses dan makna dari suatu penelitian yang selanjutnya dapat digunakan untuk membangun prediksi dan memberikan eksplanasi terhadap apa yang diteliti. Penelitian ini dilakukan pada salah satu perusahaan konstruksi di Bali yaitu PT. Megatama Karya yang berada di Jalan Sekar Jepun VI/14 A Gatsu Timur Tohpati, Denpasar 8023 Bali. PT. Megatama Karya, dimana PT. Megatama Karya merupakan perusahaan konstruksi di Bali yang sudah merambah hingga ke kancah Internasional, dengan misinya yaitu memberikan kepuasan kepada klien melalui penyelesaian proyek yang berkualitas tinggi, sesuai dengan alokasi dana yang telah dianggarkan, dan sesuai dengan perhitungan waktu yang telah disepakati, untuk mencapai itu tentu tenaga kerjanya harus dididik dan dikembangkan keterampilan serta keahliannya melalui sertifikasi kompetensi. 
Penelitian kualitatif dalam penelitian ini tidak menggunakan populasi, melainkan penelitian kualitatif berasal dari fenomena tertentu yang ada dalam situasi sosial tertentu dan hasil kajiannya tidak akan diberlakukan pada suatu populasi, akan tetapi ditransfer ke tempat lain pada situasi sosial dalam kasus yang sedang dipelajari. Subjek penelitian ini menjadi informan yang akan memberikan berbagai informasi yang diperlukan selama proses penelitian melalui wawancara. Informan dalam penelitian ini, ditentukan dengan metode purposive sampling. Informan yang dimaksud oleh peneliti yaitu informan pertama atau informan kunci yang paling sesuai adalah Tenaga Ahli Manajemen Proyek yang telah mengikuti sertifikasi keahlian kemudian Tenaga Ahli Manajemen Proyek mengarahkan informan berikutnya adalah Tenaga Ahli K3 Konstruksi, Tenaga Ahli K3 Konstruksi kemudian mengarahkan informan berikutnya adalah Mandor yang mengawasi jalannya proyek dan Mandor mengarahkan informan selanjutnya adalah Tukang Bangunan yang dianggap mampu memberikan informasi pada penelitian ini.

Analisis data merupakan kegiatan setelah data dari seluruh informan terkumpul. Data tersebut telah dianalisis dengan cara mengorganisasikan sebuah data, menjabarkan dalam unit-unit tertentu, melakukan suatu sintesa, menyusun ke dalam sebuah pola, memilih mana yang penting dan yang akan dipelajari, serta membuat sebuah kesimpulan yang dapat diceritakan kepada orang lain (Sugiyono, 2017). Pengujian keabsahan data pada penelitian ini menggunakan metode triangulasi yaitu metode pemeriksaan keabsahan data yang memanfaatkan sesuatu yang lain dalam membandingkan hasil wawancara terhadap objek penelitian. Triangulasi yang digunakan pada penelitian ini meliputi triangulasi sumber. Triangulasi sumber dilakukan untuk menguji kredibilitas data dengan cara mengecek data yang telah diperoleh melalui beberapa sumber. Triangulasi sumber data adalah menggali sebuah kebenaran dari informasi tertentu melalui berbagai metode-metode serta sumber perolehan data.

\section{PEMBAHASAN}

Dari hasil penelitian yang dilakukan melalui proses wawancara dengan beberapa informan di PT. Megatama Karya, maka ditemukan hasil penelitian yaitu sertifikasi yang telah diikuti oleh tenaga kerja konstruksi mulai dari tenaga ahli hingga tukang bangunan dirasakan sangat bermanfaat untuk peningkatan kompetensi dan kualitas kerja mereka. Adanya penyegaran informasi yang mereka terima baik itu yang menyangkut tentang tata cara mengerjakan proyek dengan prosedur yang baik dan benar hingga ketentuan-ketentuan lainnya 
sangat bermanfaat bagi perusahaan dan tenaga kerja kedepannya. Kompetensi tenaga kerja di PT. Megatama Karya, sudah mengalami peningkatan. Tetapi sekitar 50\% tenaga kerja belum mengikuti sertifikasi. Hal tersebut dapat mengurangi kepercayaan client. Oleh karena itu, pihak perusahaan perlu bertindak tegas terhadap fenomena tersebut karena sudah dijelaskan dalam UU No. 2 Tahun 2017 bahwa seluruh tenaga kerja konstruksi harus mengikuti sertifikasi. Disamping itu sertifikasi sangat berperan penting dalam meningkatkan kompetensi bisnis misalkan kualitas kerjanya menjadi lebih baik, selain itu gaji/penghasilan yang diterima dari pimpinan meningkat dari sebelumnya.

\section{Sertifikasi Tenaga Kerja Konstruksi}

Menurut para ahli ada beberapa pengertian dari sertifikasi diantaranya Nursyirwan \& Moedjiman (2007), sertifikasi adalah proses penilaian untuk mendapatkan pengakuan atas komepetensi dan kemampuan dari seseorang, untuk memenuhi persyaratan perundangundangan melalui uji kompetensi. Sedangkan menurut Cahyono (2005), adanya sertifikasi ini diharapkan akan menjadi senjata ampuh bagi terbukanya akses-akses kesempatan kerja di proyek konstruksi secara kompetitif di tingkat global. Dari hasil penelitian ditemukan bahwa nilai performansi Stakeholder Satisfaction jika ditinjau dari rata-rata KPI penyusunya adalah sebesar 3,800, sedangkan nilai performansi Stakeholder Contribution jika ditinjau dari rata-rata KPI penyusunnya adalah sebesar 3,862, dengan demikian dapat diartikan bahwa kepuasan stakeholder saat ini seimbang dengan kontribusi yang diberikan stakeholder tersebut. Terdapat beberapa penelitian terdahulu yang mendukung hasil penelitian ini seperti hasil studi yang dilakukan oleh Adi (2018), yang telah menguji tentang sertifikasi tenaga kerja konstruksi sebagai unsur pendukung pembangunan infrastruktur.

\section{Kompetensi}

Kompetensi merupakan keahlian dan keterampilan yang dimiliki oleh seseorang dalam menyelesaikan pekerjaannya. Kompetensi menggambarkan seberapa lamanya seseorang menyelesaikan pekerjaannya, apakah tepat waktu atau tidak tepat waktu. PT. Megatama Karya, diera globalisasi saat ini memerlukan tenaga kerja yang berkualitas agar proyek yang berjalan selesai sesuai dengan waktu yang telah ditetapkan. Menurut Sutrisno (2009), menyatakan bahwa kompetensi merupakan suatu karakteristik dasar dari seseorang yang kemungkinan dapat memberikan suatu kinerja yang unggul dalam pekerjaan, peran, atau situasi tertentu. Penelitian ini memiliki perbedaan dengan penelitian yang dilakukan oleh Haryadi (2010), yang 
menguji tentang kompetensi tenaga kerja konstruksi dalam menghadapi era liberalisasi, dimana kompetensi tenaga kerja konstruksi masih rendah karena belum memiliki spesialisasi dan sertifikasi pembangunan pekerja Indonesia. Sehingga mengakibatkan kegagalan selama konstruksi. penelitian terdahulu yang mendukung hasil penelitian oleh Febriarso (2008), yang menguji tentang perancangan sistem pengukuran kinerja dengan metode performance prism". Dari hasil penelitian ditemukan bahwa nilai performansi Stakeholder Satisfaction jika ditinjau dari rata-rata KPI penyusunnya adalah sebesar 3,800, sedangkan nilai performansi Stakeholder Contribution jika ditinjau dari rata-rata KPI penyusunya adalah sebesar 3,862, dengan demikian dapat diartikan bahwa kepuasan stakeholder saat ini seimbang dengan kontribusi yang diberikan stakeholder tersebut.

\section{PENUTUP}

Berdasarkan dari hasil penelitian yang dilakukan di PT. Megatama Karya dan hasil pembahasan diatas, maka dapat disimpulkan bahwa sertifikasi bukan mencentang kotak/sebatas formalitas semata, melainkan meningkatkan kompetensi bisnis. Hal tersebut dapat dikatakan oleh penulis karena sertifikasi merupakan faktor yang sangat penting untuk meningkatkan kompetensi dan kualitas kerja para tenaga kerja, karena pengetahuan dan keterampilan yang didapatkan pada program sertifikasi mampu diaplikasikan langsung di lapangan dengan maksimal, sehingga penyelesaian proyek yang dilakukan selesai tepat waktu dan terciptanya tenaga kerja yang berkompeten dan berkualitas. Tetapi kenyataanya sekitar 50\% tenaga kerja di PT. Megatama Karya belum mengikuti sertifikasi sehingga hal tersebut dapat menurunkan kepercayaan dari para client, disamping itu bagi tenaga kerja yang belum mengikuti sertifikasi tetapi tetap menjalankan pekerjaannya menyelasaikan project maka akan dikenakan sanksi administratif berupa pemberhentian dari tempat kerja sesuai dengan Pasal 70 ayat 1 UU No. 2 Tahun 2017. Oleh karena itu pihak perusahaan perlu bertindak tegas dan menggalakkan program sertifikasi kepada seluruh tenaga kerjanya agar mereka semua mengikuti pelatihan keahlian dan keterampilan kerja (sertifikasi). Hasil penelitian ini dapat dijadikan acuan oleh pimpinan PT. Megatama Karya dalam pengambilan keputusan dan bertindak tegas tentang program sertifikasi kepada seluruh tenaga kerja agar mereka yang belum mengikuti sertifikasi mau mengikuti sertifikasi. Saran yang dapat digunakan bagi peneliti selanjutnya adalah lebih banyak membahas tentang jenis-jenis sertifikasi tenaga kerja konstruksi dan perubahan apa yang dilakukan sehingga bisa diaplikasikan di perusahaan konstruksi lainnya karena pelaksanaan sertifikasi bagi karyawan merupakan kegiatan yang 
sangat bermanfaat bagi peningkatan kompetensinya. Selain itu untuk informan penelitian bisa ditambahkan sehingga hasil yang diperoleh nanti akan lebih baik dan bermanfaat. 


\section{DAFTAR PUSTAKA}

Artika, D. (2013). Pengaruh Kompetensi, Stres Kerja, Budaya Organisasi Terhadap Motivasi Kerja Karyawan RSUP Sanglah, Tesis, Program Pasca Sarjana, Magister Manajemen Universitas Warmadewa, Denpasar.

Astuti, B. (2008). Sertifikasi Uji Kompetensi Sebagai Upaya Perlindungan Hukum Bagi Tenaga Kerja Indonesia/Tenaga Kerja Wanita Penata Laksana Rumah Tangga (TKI/TKW PLRT), Tesis, Program Pasca Sarjana, Magister Hukum Universitas Diponegoro, Semarang.

Bali, I.N.A.P., and Darma, G.S. (2019). Menguji Kesiapan Pengelolaan Desa Berbasis Manajemen Modern Guna Menghadapi Era Revolusi Industri 4.0, Jurnal Manajemen \& Bisnis, 16 (2): 1-13.

Cadman, C. (2012). Employee training: Ticking the box or building business competence?. Diambil dari www.trainingzone.co.uk.

Cahyono, A. (2005). Sertifikasi Profesi, Kebutuhan atau Sekedar Persyaratan, Consulting Edisi 06/VIII/2005, Semarang.

Creswell, J. W. (1994). Reseach Design Qualitative and Quantitative, Approaches. London: Sage Publications.

Darma, G.S. (2019). Kacamata Media, Kesuksesan Bersyarat. Indonesia: Pustaka Larasan Press.

Darma, G.S. (2018). Seuntai Pesan, Menjawab Zaman. Indonesia: Pustaka Larasan Press.

Dewi, A.A.I.S., and Darma, G.S. (2017). Proses Rekrutmen, Seleksi, Pelatihan, Penempatan dan Kinerja Karyawan, Jurnal Manajemen \& Bisnis, 14 (1): 1-18.

Febriarso, P. (2008). Perancangan Sistem Pengukuran Kinerja Dengan Metode Performance Prism, Fakultas Teknik, Universitas Muhammadiyah Surakarta, Solo.

Giovanna, N., and Darma, G.S. (2019). Scanlated vs. Physical Japanese Comic Manga, International Journal of Innovative Science and Research Technology, 4 (1): 630-636.

Komandan. (2013). Pengaruh Sistem Manajemen Keselamatan dan Kesehatan Kerja (SMK3) Terhadap Kinerja Karyawan PT. Adhi Karya (Persero) Tbk, Fakultas Ilmu Sosial dan Ilmu Politik.

Mangkunegara. (2010). Evaluasi Kinerja SDM. Bandung: PT. Refika Aditama.

Moedjiman, M. (2007). Badan Nasional Sertifikasi Pekerja Tonggak Reformasi SDM. Diambil dari www.nakertrans.go.id.

Moleong, L.J. (2010). Metodologi Penelitian Kualitatif, Bandung: Remaja Rosda Karya. 
Nursyirwan, I. (2006). Tenaga Kerja Kosntruksi Indonesia Perlu Pengakuan, Buletin BPKSDM Departemen Pekerjaan Umum Vol. 3.

Purnantara, I.M.H., and Darma, G.S. (2015). Competency, Organizational Health, Job Career, Job Performance And Employees Turnover, Jurnal Manajemen \& Bisnis, 12 (2): 90124.

Rivai, V. (2009). Manajemen Sumber Daya Manusia Untuk Perusahaan Dari Teori ke Praktik. Jakarta: Raja Grafindo Persada.

Rivelino. (2017). Analisis Faktor-Faktor Yang Mempengaruhi Pelaksanaan Sertifikasi Keterampilan Kerja Tenaga Kerja Terampil Konstruksi, Magister Teknik Sipil, Universitas Katolik Parahyangan, Bandung.

Robbins, P.S. (2008). Teori Organisasi Struktur, Desain \& Aplikasi, Edisi 3. Jakarta: Arcan.

Setiawan, B., dan Haryadi. (2010). Arsitektur, Lingkungan dan Perilaku. Yogyakarta: Gadjah Mada University Press.

Simamora, H. (2010). Manajemen Sumber Daya Manusia, Edisi Kedua, STIE YKPN.

Sedarmayanti. (2011) Manajemen Sumber Daya Manusia, Reformasi Birokasi dan Manajemen Pegawai Negeri Sipil (Cetakan Kelima). Bandung: PT. Refika Aditama.

Sugiyono. (2017). Metode Penelitian Kuantitatif, Kualitatif, dan R\&D. Bandung: Alfabeta, CV.

Sulistiyani. (2013). Manajemen Sumber Daya Manusia. Yogyakarta: Graha Ilmu.

Sutrisno, E. (2009). Manajemen Sumber Daya Manusia. Jakarta: Kencana Pernada Media Group.

Tika. (2006). Budaya Organisasi Dan Peningkatan Kinerja Perusahaan. Jakarta: PT Bumi Aksara.

Wiandari, I.A.A., and Darma, G.S. (2017). Kepemimpinan, Total Quality Management, Perilaku Produktif Karyawan, Kinerja Karyawan dan Kinerja Perusahaan, Jurnal Manajemen \& Bisnis, 14 (2): 61-78.

Widana, I.W., and Darma, G.S. (2018). Branding Denpasar Smart City Guna Meningkatkan Kunjungan Wisatawan, Jurnal Manajemen \& Bisnis, 15 (1): 176-199.

Widiari, I.A.R., and Darma, G.S. (2017). Evaluasi Kinerja Pegawai Kontrak Melalui Tujuh Kompetensi Spencer Pada Pelayanan Denpasar Sewerage Development Project (DSDP), Jurnal Ilmiah Manajemen \& Bisnis, 2 (2): 360-367. 
Widiastra, I.K., and Darma, G.S. (2015). Komitmen, Kepuasan Kerja, Organizational Citizenship Behavior dan Kinerja Pegawai Kontrak, Jurnal Manajemen \& Bisnis, 12 (2): $214-241$.

Wibowo. (2012). Manajemen Kinerja. Jakarta: PT. Raja Grafindo Persada.

Widiasanti. (2014). Persepsi Tenaga Kerja Ahli Jasa Konstruksi Terhadap Penyelenggaraan Sertifikasi Oleh Unit Sertifikasi Tenaga Kerja Lembaga Pengembangan Jasa Konstruksi, Fakultas Teknik, Universitas Negeri Jakarta, Jakarta.

Yuliana, C. (2011). Studi Pemahaman dan Penerapan Standard Kompetensi Keterampilan Kerja Tenaga Kerja pada Pelaksanaan Proyek Konstruksi, Fakultas Teknik, Universitas Lambung Mangkurat, Banjarmasin. 